\title{
PW02-002 - Single MVK mutation and recurrent fevers
}

\author{
K Barron $^{1 *}$, A Ombrello $^{1}$, D Goldsmith², I Aksentijevich ${ }^{1}$, A Jones ${ }^{1}$, D Kastner ${ }^{1}$ \\ From 7th Congress of International Society of Systemic Auto-Inflammatory Diseases (ISSAID) \\ Lausanne, Switerland. 22-26 May 2013
}

\section{Introduction}

HyperIgD syndrome is an autoinflammatory disorder caused by mutations in the $M V K$ gene. While mutations in most patients follow autosomal recessive inheritance, we have identified a cohort of patients with recurrent fevers and only 1 mutation in the $M V K$ gene.

\section{Objectives}

To compare clinical features in those with 1 vs. $2 M V K$ mutations and to report therapeutic responses in all.

Patients were evaluated at the NIH. Clinical and laboratory information were collected at each visit.

\section{Methods}

Patients were evaluated at the NIH. Clinical and laboratory information were collected at each visit.

\section{Results}

31 pts with mutations in $M V K$ were evaluated: 22 had 2 mutations (21 with V377I and 1 other mutation; 1 with V203A/H380R), 9 had only 1 mutation after testing the whole gene (8 with V377I, 1 with I268V). The carrier frequency of V377I in our control Caucasian population is $0.3 \%(2 / 739)$. In contrast, in 344 independent cases of recurrent fever submitted for $M V K$ testing, 8 bore a single copy of V377I for a frequency of $2.3 \%$.

Clinical or laboratory presentation at the time of a flare was compared between the 2 groups. There was no significant difference with regard to age of onset, duration of flares, frequency of flares, flares after immunizations, GI symptoms, oral ulcers, sore throat, arthralgia, or adenopathy associated with flares. Rash was more common in pts with 2 mutations, 20/22 compared to $4 / 9$ in those with one mutation $(\mathrm{p}=.01)$. While there was no difference in level of IgG, IgA was increased in those with 2 mutations
$(452 \pm 230 \mathrm{mg} / \mathrm{dl})$ compared to those with 1 mutation $(230 \pm 175)(\mathrm{p}=.01)$, as well as level of IgD, $(95 \pm 95,2$ mutations, vs. $8.3 \pm 7.4,1$ mutation, $\mathrm{p}=.01$ )

Since there was no significant difference in clinical presentation, other than presence of rash and levels of IgA and IgD, pts were considered together to evaluate their therapeutic responses. Of 8 pts treated with colchicine, 7 reported no response, 1 reported some improvement. Of 27 pts treated with prednisone at the time of a flare, 18 noted some improvement; 7 reported either none or shortening of the interval before next flare. Of 15 pts receiving montelukast, 4 reported some improvement; 11 reported none. Of 19 pts receiving intermittent anakinra at the time of a flare, 13 reported some improvement, 3 too early to assess efficacy, and 3 no improvement including one who developed acute renal failure. 5 pts received daily anakinra, with 4 reporting some improvement and 1 too early to assess. Of 9 pts receiving etanercept, 4 reported improvement, 5 report none.

\section{Conclusion}

Aside for the presence of rash and higher IgA and $\operatorname{IgD}$ levels in those children with $2 M V K$ mutations, there are no significant clinical differences between these groups. There are no clear trends that allow identification or predictability of the disease course in children with either 1 or 2 mutations. Given the higher frequency of V377I heterozygotes in our patient cohort compared to the general population, our data suggest that under some circumstances this may be associated with recurrent fevers. Therapeutic options for children with $M V K$ mutations include intermittent prednisone or anakinra, either given intermittently or daily; however, not all patients respond to therapy and there are associated adverse events in some patients.

${ }^{1}$ National Institutes of Health, Bethesda, PA, USA

Full list of author information is available at the end of the article

(C) 2013 Barron et al; licensee BioMed Central Ltd. This is an Open Access article distributed under the terms of the Creative Commons 


\section{Disclosure of interest}

None declared.

\section{Authors' details}

${ }^{1}$ National Institutes of Health, Bethesda, PA, USA. ${ }^{2}$ Drexel University Coll Med,

PA, USA

Published: 8 November 2013

doi:10.1186/1546-0096-11-S1-A142

Cite this article as: Barron et al:: PW02-002 - Single MVK mutation and

recurrent fevers. Pediatric Rheumatology 2013 11(Suppl 1):A142.

Submit your next manuscript to BioMed Central and take full advantage of:

- Convenient online submission

- Thorough peer review

- No space constraints or color figure charges

- Immediate publication on acceptance

- Inclusion in PubMed, CAS, Scopus and Google Scholar

- Research which is freely available for redistribution

Submit your manuscript at www.biomedcentral.com/submit 